\section{REPUBLIC OF SINGAPORE}

Area: 617.8 sq. km

Population: 2,502,000

Head of State: Devan Nair (President)

Minister of Home Affairs: S. Jaya Kumar

Emergency services: 999

\section{ORGANIZATION}

The Republic of Singapore Police is organized into 11 divisions, 8 of which are territorial and the remainder functional:

$$
\begin{aligned}
& \text { A - Central } \\
& \text { B - Toa Payoh } \\
& \text { C - Beach Road } \\
& \text { D - Queenstown } \\
& \text { E - Tanglin } \\
& \text { F - Paya Lebar } \\
& \text { G - Joo Chiat } \\
& \text { J - Jurong } \\
& \text { M - Marine } \\
& \text { R - Radio } \\
& \text { T - Traffic }
\end{aligned}
$$

High priority is given to crime-fighting. The Criminal Investigation Department is a modern and efficient unit, supported by the Police Criminal Records Office and a Data Processing Centre. The CID includes a Special Investigation Section, the Commercial Crime Division, and four specialist branches: Organized Crime, Gambling Suppression, Secret Societies Investigation and Prosecution. The emphasis on checking potentially subversive organizations (which in the Far East are mainly various secret societies) is reflected in the existence of a Registry of Societies, and even a Martial Arts Control Unit (both agencies are associated with the police but not part of it). The CID also controls the Anti-Vice Enforcement Unit.

Other police branches include Traffic and the Immigration Department, which maintains an Airport Division. There are three Police Task Forces (TF 1, at Mount Vernon; TF 2, at Queensway; TF 3, at Jalau Bahar), a Gurkha Contingent for riot control (another is in charge of prison guard duties) and a Police Dog Unit.
Basic training is provided at the Police Training Centre; specialist and advanced training is given at the Police Academy.

The Police also enlists the assistance of citizens of the Republic through the Vigilante Corps-which is related to the Civil Defence Organization and shares its Headquarters with the Civil Defence School. There is a Vigilante Corps officer at each Divisional Headquarters.

Although it co-operates very closely with the police, the Central Narcotics Bureau is in fact a separate agency within the Ministry of Home Affairs. It comprises four divisions: Administration, Enforcement, Intelligence and Supervision.

Police HQ, Phoenix Park, Tanglin Road, Singapore (235 9111)

Police Academy, Singapore (256 4466)

Police Training Centre, Singapore (255 4656)

Central Narcotics Bureau, Eu Tong Sen Street, Singapore (91 3344)

\section{OPERATIONS}

The severe attitude to crime adopted by the government of Singapore has been remarkably successful. The Republic is one of the most orderly countries in the world, sharply contrasting with other South Asian areas. Police powers are comprehensive (the CID includes a Prosecution Branch). Courts deal harshly with habitual offenders, regardless of their nationality; and corruption in high places, historically common in Asia, is noticeably absent.

Drug abuse has been brought under control (the death penalty is imposed on drug dealers). Offenders apprehended by the police are liable to compulsory therapy. There are three Drug Rehabilitation Centres in operation for that purpose: Selarang Park and Sembawang for males, and Moon Crescent (annexed to the women's prison) for females.

\section{PRIVATE SECURITY}

The main private security companies in Singapore are:

Maniam Enterprises (Pte) Ltd, 151 Cavenagh Court, Singapore (737 2542)

Sigma Security Services (Pte) Ltd, 101 Nehson's Building, Singapore (220 0746) 